\title{
Development of a water quality index based on a European classification scheme
}

\author{
Hülya Boyacioglu \\ Dokuz Eylul University, Faculty of Engineering, Department of Environmental Engineering, \\ Tinaztepe Campus Buca 35160 Izmir, Turkey
}

\begin{abstract}
This study comprised the development of a new index called the 'universal water quality index (UWQI)'. This index has advantages over pre-existing indices by reflecting the appropriateness of water for specific use, e.g. drinking water supply rather than general supply, and has been developed by studying the supranational standard, i.e. the European Community Standard. Three classification schemes for water quality are proposed for surface water quality assessment. Water quality determinants of the new index are cadmium, cyanide, mercury, selenium, arsenic, fluoride, nitrate-nitrogen, dissolved oxygen, biochemical oxygen demand, total phosphorus, $\mathrm{pH}$ and total coliform. The mathematical equations to transform the actual concentration values into quality indices have been formulated. The weighted sum method was proposed to obtain overall index scores based on individual index (sub-index) values. The application of the new index was demonstrated at a sampling station on Tahtali Reservoir in Turkey based on observed water quality data. Results revealed that the overall quality of the surface water falls under the 'excellent' class. On the other hand water quality was strongly affected by agricultural and domestic uses. This technique is believed to assist decision makers in reporting the state of the water quality, as well as investigating spatial and temporal changes. It is also useful to determine the level of acceptability for the individual parameter by referring to the concentration ranges defined in the proposed classification scheme.
\end{abstract}

Keywords: sub-index value, Tahtali Reservoir, water quality determinant, water quality index, water quality standard

\section{Introduction}

The quality of water is defined in terms of its physical, chemical and biological parameters, and ascertaining its quality is crucial before use for various intended purposes such as potable water, agricultural, recreational and industrial water uses, etc. (Sargaonkar and Deshpande, 2003). A major objective of water quality assessment is to determine whether or not the water quality meets previously defined objectives for designated uses, to describe water quality at regional, national or international scales, and also to investigate trends in time, etc.

Traditional approaches to assessing water quality are based on a comparison of experimentally determined parameter values with existing guidelines. In many cases, the use of this methodology allows proper identification of contamination sources and may be essential for checking legal compliance. However, it does not readily give an overall view of the spatial and temporal trends in the overall water quality in a watershed (Debels et al., 2005).

One of the difficult tasks facing environmental managers is how to transfer their interpretation of complex environmental data into information that is understandable and useful to technical and policy individuals as well as the general public. This is particularly important in reporting the state of the environment. Internationally, there have been a number of attempts to produce a method that meaningfully integrates the data sets and converts them into information (Nagels et al., 2001).

Since 1965, when Horton (1965) proposed the first water quality index (WQI), a great deal of consideration has been given

学 +9023241271 31; fax: +9023245311 43;

e-mail: hulya.boyacioglu@deu.edu.ti

Received 24 August 2006; accepted in revised form 21 October 2006. to the development of 'water quality index' methods with the intent of providing a tool for simplifying the reporting of water quality data (Liou et al., 2004). WQI improves understanding of water quality issues by integrating complex data and generating a score that describes water quality status and evaluates water quality trends. These indices assess the appropriateness of the quality of the water for a variety of uses (Cude, 2001). They are considered more appropriate for disseminating information to general audiences.

The WQI concept is based on the comparison of the water quality parameter with respective regulatory standards (Khan et al., 2003). The development process of a water quality index can be generalised in four steps:

- Selecting the set of water quality variables of concern parameter selection

- Transformation of the different units and dimensions of water quality variables to a common scale - developing sub-indices

- Weighting of the water quality variables based on their relative importance to overall water quality - assignment of weights

- Formulation of overall water quality index - aggregation of sub-indices to produce an overall index (Harrison et al., 2000).

\section{Universal Water Quality Index (UWQI)}

In this study a new index called the Universal Water Quality Index (UWQI) was developed to provide a simpler method for describing the quality of the surface water used for drinking water supply. UWQI has advantages over pre-existing indices by reflecting appropriateness of water for specific use - drinking water supply rather then general supply and has been developed by studying the supranational standard. Previous indices 


\begin{tabular}{|c|c|c|c|c|c|}
\hline \multicolumn{6}{|c|}{$\begin{array}{c}\text { TABLE } 1 \\
\text { Classification of water quality for the development of UWQI }\end{array}$} \\
\hline Parameter & Unit & $\begin{array}{c}\text { Class I } \\
\text { (excellent) }\end{array}$ & $\begin{array}{c}\text { Class II } \\
\text { (acceptable) }\end{array}$ & $\begin{array}{c}\text { Class III } \\
\text { (polluted) }\end{array}$ & Remark \\
\hline Total Coliform & $\mathrm{CPU} / 100 \mathrm{~m} \ell$ & 50 & 5000 & 50000 & $\begin{array}{l}\text { It is used to indicate whether other potentially harmful } \\
\text { bacteria may be present }\end{array}$ \\
\hline Cadmium & $\mathrm{mg} / \ell$ & 0.003 & 0.005 & 0.010 & \multirow{3}{*}{ Chemicals from industrial and domestic discharges } \\
\hline Cyanide & $\mathrm{mg} / \ell$ & 0.010 & 0.050 & 0.100 & \\
\hline Mercury & $\mathrm{mg} / \ell$ & 0.0001 & 0.0005 & 0.002 & \\
\hline Selenium & $\mathrm{mg} / \ell$ & 0.010 & 0.010 & 0.020 & \multirow{3}{*}{ Naturally occurring chemicals } \\
\hline Arsenic & $\mathrm{mg} / \ell$ & 0.020 & 0.050 & 0.100 & \\
\hline Fluoride & $\mathrm{mg} / \ell$ & 1 & 1.5 & 2 & \\
\hline Nitrate-nitrogen & $\mathrm{mg} / \ell$ & 5 & 10 & 20 & Chemicals from agricultural activities \\
\hline DO & $\mathrm{mg} / \ell$ & 8 & 6 & 3 & \multirow{2}{*}{ Operational monitoring parameters } \\
\hline $\mathrm{pH}$ & & $6.5-8.5$ & $\begin{array}{c}5.5-6.4 \\
8.6-9\end{array}$ & $\begin{array}{l}<5.5 \\
>9\end{array}$ & \\
\hline BOD & $\mathrm{mg} / \ell$ & $<3$ & $<5$ & $<7$ & Indicator of organic pollution \\
\hline $\begin{array}{l}\text { Total phospho- } \\
\text { rus- } \mathrm{PO}_{4}-\mathrm{P}\end{array}$ & $\mathrm{mg} / \ell$ & 0.02 & 0.16 & 0.65 & $\begin{array}{l}\text { It is included to satisfy the ecological requirements of } \\
\text { certain types of environment }\end{array}$ \\
\hline
\end{tabular}

were mostly developed in order to assess stream-water quality for general recreational uses. In addition they were based on the national standards of any particular country and this limited their application to within the country of origin.

The UWQI was developed on the basis of the following water quality standards:

- 'The quality required of surface water intended for the abstraction of drinking water in the Member States 75/440/ EEC' set by the Council of the European Communities (EC, 1991)

- 'The classification of inland waters according to quality Turkish water pollution control regulation - WPCR' (Official Gazette, 1988)

- Other reported scientific information

According to EC legislation (75/440/EEC), water quality of surface waters intended for the abstraction of drinking water is classified into three groups. For each class the treatment level required to transform surface water into drinking water is different and can be summarised as:

- Class I: Simple physical treatment and disinfection, e.g. rapid filtration and disinfection

- Class II: Normal physical treatment, chemical treatment and disinfection, e.g. pre-chlorination, coagulation, flocculation, decantation, filtration, disinfection (final chlorination)

- Class III: Intensive physical and chemical treatment, extended treatment and disinfection, e.g. chlorination to break-point, coagulation, flocculation, decantation, filtration, adsorption (activated carbon), disinfection (ozone, final chlorination) (EC, 1991).

This classification is based on the assessment of about 45 water quality parameters including physical, chemical and microbiological variables such as temperature, $\mathrm{pH}$, colour, sodium, biochemical oxygen demand, mercury, lead, iron and total coliform, etc. Each class is characterised by numerical values for these parameters. Turkish WPCR also has quite a similar categorisation scheme, the main difference being that a Category IV is added to the Turkish standard water quality parameters, in which the values exceed those set for Category III. In this study a $4^{\text {th }}$ class was excluded when considering appropriateness of water for potable purposes. UWQI parameters (water quality determinants) were selected among these 45 parameters. The concentration ranges of the determined variables for three categories were defined by referring to the 75/440/EEC and Turkish WPCR. In general among both standards the more restricted value for each class was accepted as the reference value.

After water quality variables of the index had been determined, mathematical equations which transformed the actual concentration values into individual quality indices were formulated for all the parameters. Assignment of weights to variables was followed by aggregation of sub-indices using the weighted sum method to obtain an overall index value.

Selection of water quality determinants: In drinking water quality monitoring, priority should be given to those substances which are known to be of importance to health and which are known to be present in significant concentrations in the water source (WHO, 2006a). Experience has shown that microbial hazards continue to be the primary concern in both developing and developed countries (WHO, 2004a). Based on the fact that microbiological contaminants have the greatest health impact this category has the highest priority in water quality monitoring. In addition it is important that monitoring of chemical water quality is linked to a process of hazard identification and risk assessment. There are a number of parameters that, when used in conjunction with a pollution source assessment, provide a good overall indication of chemical water quality. These parameters and others whose impact on human health or the environment are great should be included in initial testing. The presence at high levels of these pollutants in the source water may indicate that other analyses are required. These variables include nitrate, $\mathrm{pH}$, fluoride and dissolved oxygen (WHO, 2006b). Furthermore, in assessing the chemical water quality, it is also important to consider arsenic and selenium. Extensive international experience has shown that when arsenic, selenium, fluoride and nitrate are present in excessive quantities they cause widespread detrimental health effects in humans as a consequence of exposure through drinking water (WHO, 2004b). Arsenic, selenium and fluoride occur in water naturally. Nitrate may naturally occur but can also originate from agricultural sources, sewage disposal and urban runoff. Agricultural sources may indicate that there will also be a problem 
with other agricultural pollutants such as pesticides (WHO, 2004b). Toxic chemicals in drinking water such as cadmium, cyanide, mercury, etc. should also be included in the initial testing, because their existence in drinking water causes more serious health effects compared to the others. Even some parameters such as $\mathrm{pH}$ or dissolved oxygen are not set at international drinking water standards and have direct health effects, so it may be important to assess the performance of control measures at appropriate time intervals.

All these factors were taken into account in selecting water quality determinants of the UWQI. Faecal coliform has been included as indicator parameter of microbial contamination for UWQI. In order to prevent long-term health effects from exposure to contaminants, second priority was given to nitrate, arsenic, selenium, fluoride, cadmium, cyanide and mercury. Operational monitoring parameters such as dissolved oxygen and $\mathrm{pH}$ were also selected for UWQI calculation. Finally, biochemical oxygen demand (BOD), an indicator of organic pollution in water and phosphorus, was included to satisfy the ecological requirements of certain types of environment.

Sub-index development: The proposed classification for UWQI along with ranges of concentrations of selected parameters based on standards is given in Table 1.

Considering the required level of treatment, in this study each class of water is assigned as:

- Class I: excellent

- Class II: acceptable

- Class III: polluted

Sub-indices are value functions (rating curves) to transform the different units and dimensions of water quality variables to a common scale. Development of rating curves is highly subjective and mostly based on the judgment of the author and a few of his associates. In this study opinions of the 14 water experts working at different institutions were asked about this process. They agreed to assign fixed sub-index values for reference concentration values to formulate equations. Accordingly, if the content of a detected parameter was lower than the value set for Class I the water quality sub-index was automatically registered ' 100 '. Similarly for the variable that exceeds the value set for Class III, the water quality sub-index was registered ' 0 '. A fixed sub-index value which corresponds to the values in the 'acceptable class' category was assigned as ' 50 '.

Mathematical expressions were fitted for each parameter to obtain these fixed sub-index values $(0,50$ and 100) against reference concentrations. Regression analysis was performed for this purpose using the 'Statistical Package for the Social Science Software-SPSS-10.0 for Windows'. Mathematical equations are given in Table 2.

Overall index calculation - aggregation of sub-indices: Aggregation of sub-indices was performed using the weighted sum method. The assignment of weights to water quality variables was another task. Factors taken into account for the assignment process are summarised as:

- Chemical parameters had a lower weight than microbiological parameters, because microbial contaminants belong to the greatest health impact category

- High weight was given to those parameters of known health concern

The temporary weights ranged from 1 to 4 on a basic scale of importance. On this scale 1, 2, 3 and 4 denote respectively little,

\begin{tabular}{|c|c|c|}
\hline \multicolumn{3}{|c|}{$\begin{array}{c}\text { TABLE } 2 \\
\text { Mathematical equations formulated for UWQI }\end{array}$} \\
\hline Variable & Range & Sub-index function \\
\hline BOD & $\begin{array}{l}X<3 \\
3 \leq X<5 \\
5 \leq X<7 \\
X \geq 7\end{array}$ & $\begin{array}{l}y=100 \\
y=-25 X+175 \\
y=-22.5 X+162.5 \\
y=0\end{array}$ \\
\hline Nitrate & $\begin{array}{l}X \leq 5 \\
5<X \leq 10 \\
10<X \leq 20 \\
X>20\end{array}$ & $\begin{array}{l}y=100 \\
y=-10 X+150 \\
y=-4.5 X+95 \\
y=0\end{array}$ \\
\hline Arsenic & $\begin{array}{l}\mathrm{X} \leq 0.02 \\
0.02<\mathrm{X} \leq 0.05 \\
0.05<\mathrm{X} \leq 0.1 \\
\mathrm{X}>0.1\end{array}$ & $\begin{array}{l}y=100 \\
y=-1666.7 X+133.33 \\
y=-900 X+95 \\
y=0\end{array}$ \\
\hline $\begin{array}{l}\text { Dissolved } \\
\text { oxygen }\end{array}$ & $\begin{array}{l}X \geq 8 \\
8<X \leq 6 \\
6<X \leq 3 \\
X<3 \\
\end{array}$ & $\begin{array}{l}y=100 \\
y=25 X-100 \\
y=15 X-40 \\
y=0\end{array}$ \\
\hline Fluoride & $\begin{array}{l}X \leq 1 \\
1<X \leq 2 \\
X>2\end{array}$ & $\begin{array}{l}y=100 \\
y=-95 X+194.17 \\
y=0\end{array}$ \\
\hline $\begin{array}{l}\text { Total } \\
\text { phosphorus }\end{array}$ & $\begin{array}{l}X \leq 0.02 \\
0.02<X \leq 0.16 \\
0.16<X \leq 0.65 \\
X>0.65\end{array}$ & $\begin{array}{l}y=100 \\
y=-357.14 X+107.14 \\
y=-91.837 X+64.694 \\
y=0\end{array}$ \\
\hline Mercury & $\begin{array}{l}X \leq 0.0001 \\
0.0001<X \leq 0.0005 \\
0.0005<X \leq 0.002 \\
X>0.002\end{array}$ & $\begin{array}{l}y=100 \\
y=-125000 X+112.5 \\
y=-30000 X+65 \\
y=0\end{array}$ \\
\hline Selenium & $\begin{array}{l}X \leq 0.01 \\
0.01<X \leq 0.02 \\
X>0.02\end{array}$ & $\begin{array}{l}y=100 \\
y=4500 x+95 \\
y=0\end{array}$ \\
\hline Cyanide & $\begin{array}{l}X \leq 0.01 \\
0.01<X \leq 0.05 \\
0.05<X \leq 0.1 \\
X>0.1\end{array}$ & $\begin{array}{l}y=100 \\
y=-1250 X+112.5 \\
y=-900 X+95 \\
y=0\end{array}$ \\
\hline Cadmium & $\begin{array}{l}X \leq 0.003 \\
0.003<X \leq 0.005 \\
0.005<X \leq 0.010 \\
X>0.010\end{array}$ & $\begin{array}{l}y=100 \\
y=-25000 X+175 \\
y=-9000 X+95 \\
y=0\end{array}$ \\
\hline $\begin{array}{l}\text { Total } \\
\text { coliform }\end{array}$ & $\begin{array}{l}X \leq 50 \\
50<X \leq 5000 \\
5000<X \leq 50000 \\
X>50000\end{array}$ & $\begin{array}{l}y=100 \\
y=-10.857 \ln X+142.47 \\
y=-21.715 \ln X+284.95 \\
y=0\end{array}$ \\
\hline $\mathrm{pH}$ & $\begin{array}{l}6.5 \leq X \leq 8.5 \\
5.5 \leq X \leq 6.4 \text { and } \\
8.6 \leq X \leq 9 \\
X<5.5 \text { and } X>9\end{array}$ & $\begin{array}{l}y=100 \\
y=50 \\
y=0\end{array}$ \\
\hline
\end{tabular}

average, great and very great importance. Each weight was then divided by the sum of all weights to arrive at the final weight factor (see Table 3).

The aggregation function is represented as:

$$
U W Q I=\sum_{i=1}^{n} w_{i} I_{i}
$$

where:

$\mathrm{W}_{\mathrm{i}}=$ weight for $\mathrm{i}^{\text {th }}$ parameter

$\mathrm{I}_{\mathrm{i}}{ }^{\mathrm{i}}=$ sub-index for $\mathrm{i}^{\text {th }}$ parameter (symbolises with 'y' of Table 2) 


\begin{tabular}{|l|l|c|c|}
\hline \multicolumn{4}{|c|}{$\begin{array}{c}\text { TABLE 3 } \\
\text { Significance ratings and weights assigned to } \\
\text { variables of concern }\end{array}$} \\
\hline Category & Variable & Rating & Weight factor \\
\hline Health hazard & Total coliform & 4 & 0.114 \\
\cline { 2 - 4 } & Cadmium & 3 & 0.086 \\
\cline { 2 - 4 } & Cyanide & 3 & 0.086 \\
\cline { 2 - 4 } & Mercury & 3 & 0.086 \\
\cline { 2 - 4 } & Selenium & 3 & 0.086 \\
\cline { 2 - 4 } & Arsenic & 4 & 0.113 \\
\cline { 2 - 4 } & Fluoride & 3 & 0.086 \\
\cline { 2 - 4 } & Nitrate-nitrogen & 3 & 0.086 \\
\hline \multirow{5}{*}{$\begin{array}{l}\text { Operational } \\
\text { monitoring }\end{array}$} & DO & 4 & 0.114 \\
\cline { 2 - 4 } & pH & 1 & 0.029 \\
\hline $\begin{array}{l}\text { Oxygen } \\
\text { depletion }\end{array}$ & BOD & 2 & 0.057 \\
\cline { 2 - 4 } & Total phosphorus & 2 & 0.057 \\
\hline
\end{tabular}

Considering treatment required to transform surface water into drinking water and based on expert opinions the proposed UWQI index categorisation scheme is given in Table 4 .

\begin{tabular}{|l|l|}
\hline \multicolumn{2}{|c|}{ UWQI index categorisation scheme } \\
\hline Rank & WQI value \\
\hline Excellent & $95-100$ \\
\hline Good & $75-94$ \\
\hline Fair & $50-74$ \\
\hline Marginal & $25-49$ \\
\hline Poor & $0-24$ \\
\hline
\end{tabular}

The index value between 0 to less than 25 represents poor quality, 25 to less than 50 marginal quality, 50 to 75 fair quality, 75 to less than 95 good quality and above excellent quality.

\section{Application of UWQI to Tahtali Reservoir water quality data}

The proposed water quality classification scheme was applied to assess the water quality status at Tahtali Reservoir, which is the main drinking water reservoir for the City of Izmir in Turkey. Tahtali Basin is located in the western part of the country. Location of the Basin is shown in Fig. 1. The climate of the region is typically Mediterranean: hot and dry in summers and temperate and rainy in winters. The land area of the Tahtali Basin is approximately $550 \mathrm{~km}^{2}$, with forest and agriculture as the primary land uses. The region has long been subjected to rapid increases in population since the 1990s and 60000 people live in the catchment area as of 2000. The existing situation in that region is that this water is the main source for many decades for Izmir City where approximately three million inhabitants live. This conclusion increases the priority to protect the Basin water with respect to pollution and over-abstraction (Alpaslan et al., 2002).

The water quality data of the unique observation site in the reservoir were considered for estimation of UWQI. The subset of the data included 12 parameters for index calculation. Descriptive statistics of these parameters are presented in Table 5. Statistical calculations were performed using SPSS 10.0 for Windows.

In the second step sub-index values were calculated using

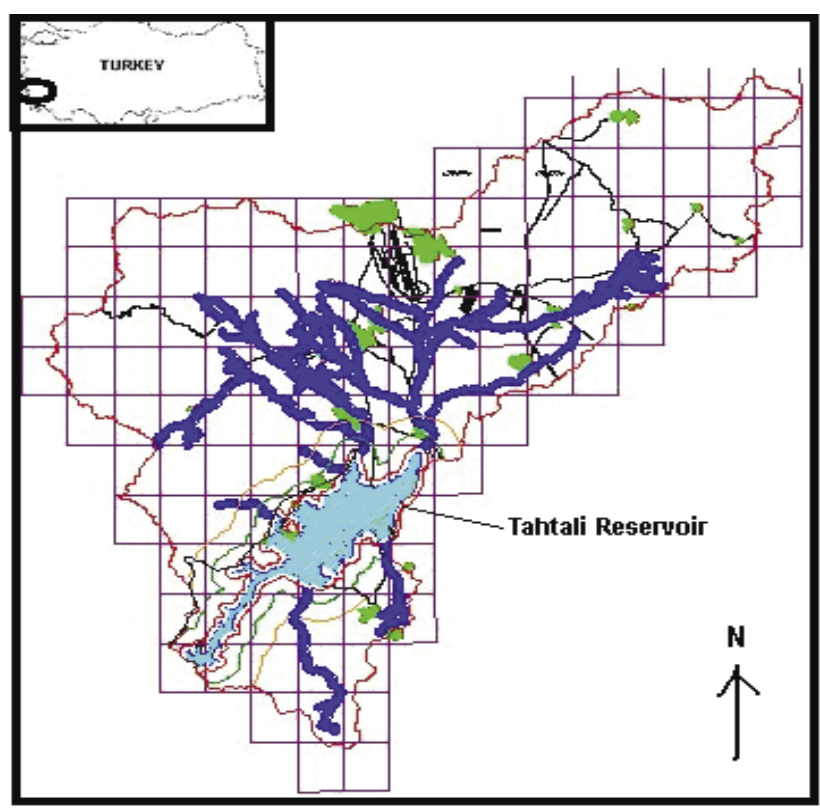

Figure 1

Location of Tahtali Basin WQI

mathematical expressions that were given in Table 2 to assign each parameter a value of between 0 and 100 . To calculate the sub-indices, the characteristic value was accepted as $90^{\text {th }}$ percentile of data set for each parameter. In the last step a weighted sum method was employed to obtain overall index values using weights which are given in Table 3 . Results are presented in Table 6.

The index value was calculated as 94.5 which almost fell under the 'excellent water' class (index value between 95 and 100. See Fig. 2). On the other hand sub-index values were the lowest for the parameters total phosphorus, $\mathrm{BOD}_{5}$, nitratenitrogen and also total coliform. Low values for nitrate-nitrogen and total phosphorus can be explained by the presence of agricultural activities in the basin where $18 \%$ of the total area is agricultural land. In addition, low $\mathrm{BOD}_{5}$ and total coliform sub-indices were the indicators of negative effects of the domestic discharges caused by urbanisation. As has been mentioned above, the region has long been subjected to rapid increases in population since the 1990 s and 60000 people live in the catchment area as of 2000. In spite of all the preventative measures taken by the local authorities, it is clear that domestic discharges and agricultural activities are major threats to reservoir water quality.

\section{Conclusion}

This study comprised the evolution of a new index called the Universal Water Quality Index (UWQI). It provides a simple representation of the extensive and complex variables (physical, biological and chemical) that govern the overall quality of surface water that is intended for potable use. Based on expert opinions and international experiences, 12 water quality parameters including cadmium, cyanide, mercury, selenium, arsenic, fluoride, nitrate, dissolved oxygen, $\mathrm{BOD}$, phosphorus, $\mathrm{pH}$ and total coliform were considered as the significant indicator parameters of UWQI to assess the quality of surface water sources. The application of the new index was demonstrated at a sampling station on Tahtali Reservoir in Turkey based on observed water quality data. Results revealed that the overall quality of the 


\begin{tabular}{|l|c|c|c|c|c|c|c|}
\hline \multicolumn{7}{|c|}{ TABLE 5 } \\
\hline Descriptive statistics of reservoir water quality data set \\
\hline Variable & Unit & $\begin{array}{c}\text { Number } \\
\text { of data }\end{array}$ & Mean & Median & Mode & Minimum & Maximum \\
\hline Cadmium & $\mathrm{mg} / \ell$ & 31 & 0.003 & 0.003 & 0 & 0 & 0.004 \\
\hline Cyanide & $\mathrm{mg} / \ell$ & 31 & 0.0009 & 0.001 & 0 & 0 & 0.0030 \\
\hline Mercury & $\mathrm{mg} / \ell$ & 30 & 0,00004 & 0 & 0 & 0 & 0.0002 \\
\hline Selenium & $\mathrm{mg} / \ell$ & 31 & 0.002 & 0.002 & 0 & 0 & 0.0080 \\
\hline Arsenic & $\mathrm{mg} / \ell$ & 31 & 0.002 & 0.002 & 0.002 & 0 & 0.010 \\
\hline Fluoride & $\mathrm{mg} / \ell$ & 31 & 0.4548 & 0.440 & 0.1 & 0.1 & 0.85 \\
\hline Nitrate-nitrogen & $\mathrm{mg} / \ell$ & 31 & 3.9419 & 4.20 & 1.6 & 1.4 & 6.4 \\
\hline DO & $\mathrm{mg} / \ell$ & 31 & 6.5365 & 7 & 8.7 & 0.9 & 13.2 \\
\hline BOD & $\mathrm{mg} / \ell$ & 31 & 2.4064 & 2 & 1 & 1 & 4.8 \\
\hline Total phosphorus & $\mathrm{mg} / \ell$ & 31 & 0.0325 & 0.01 & 0 & 0 & 0.16 \\
\hline $\mathrm{pH}$ & & 31 & 7.88 & 7.9 & 7.9 & 7.5 & 8.2 \\
\hline Total coliform & $\mathrm{CPU} / 100 \mathrm{~m} \ell$ & 31 & 104 & 90 & 170 & 10 & 185 \\
\hline
\end{tabular}

\begin{tabular}{|l|c|c|c|c|}
\hline \multicolumn{5}{|c|}{$\begin{array}{c}\text { TABLE } 6 \\
\text { An example of Universal Water Quality Index } \\
\text { (UWQI) calculation for Tahtali Reservoir }\end{array}$} \\
\hline Variable & $\begin{array}{c}\mathbf{9}^{\text {th }} \text { per- } \\
\text { centile }\end{array}$ & $\begin{array}{c}\text { Sub- } \\
\text { index }\end{array}$ & $\begin{array}{c}\text { Weight } \\
\text { factor }\end{array}$ & $\begin{array}{c}\text { Sub- } \\
\text { total }\end{array}$ \\
\hline Cadmium & 0.003 & 100 & 0.086 & 8.6 \\
\hline Cyanide & 0.002 & 100 & 0.086 & 8.6 \\
\hline Mercury & 0.0001 & 100 & 0.086 & 8.6 \\
\hline Selenium & 0.0068 & 100 & 0.086 & 8.6 \\
\hline Arsenic & 0.0058 & 100 & 0.113 & 11.3 \\
\hline Fluoride & 0.792 & 100 & 0.086 & 8.6 \\
\hline Nitrate-nitrogen & 5.84 & 91.6 & 0.086 & 7.9 \\
\hline DO & 9.62 & 100 & 0.114 & 11.4 \\
\hline BOD & 4.16 & 71 & 0.057 & 4.0 \\
\hline Total phosphorus & 0.098 & 72.14 & 0.057 & 4.1 \\
\hline pH & 8.18 & 100 & 0.029 & 2.9 \\
\hline Total coliform & 170 & 86.71 & 0.114 & 9.9 \\
\hline WQI & & & & 94.5 \\
\hline
\end{tabular}

Water quality assessment by means of an index is easier than comparing experimentally determined parameter values with existing guidelines. This new index is believed to assist decision makers in reporting the state of the water quality, and investigation of spatial and temporal changes. In addition it is useful to determine the level of acceptability for the individual parameter by referring to the concentration ranges defined in the proposed classification scheme.

\section{Acknowledgments}

The author expresses their special thanks to members of the Izmir Water and Sewerage Authority (IZSU) for their assistance in providing necessary data for the study. The author also acknowledges the contribution of Prof. Dr.-Ing. Dr. he mult. Franz Nestmann and Dr. -Ing. Punit Singh from the Karlsruhe University, Faculty of Civil Engineering, Geo and Environmental Sciences.

\section{References}

ALPASLAN MN, BOYACIOGLU H and DOLGEN D (2002) Water quality assessment and control in drinking water reservoirs by deductive approach. Proc. $9^{\text {th }}$ Int. Spec. Conf. on River Basin Management. 11-13 September 2002, Edinburgh, Scotland, UK. Preprint CD.

CUDE C (2001) Oregon Water Quality Index: a tool for evaluating water quality management effectiveness. J. Am. Water Resour. Assoc. 37 (1) $125-137$.

DEBELS P, FIGUEROA R, URRUTIA R, BARRA R and NIELL $X$ (2005) Evaluation of water quality in the Chilla'n River (Central Chile) using physicochemical parameters and a modified water quality index. Environ. Monit. Assess. 110 301-322.

EC (EUROPEAN COUNCIL) (1991) Consolidated Text Produced by the CONSLEG System of the Office for Official Publications of the European Communities. Council Directive of 16 June 1975 Concerning the Quality Required of Surface Water Intended for the Abstraction of Drinking Water in the Member States (75/440/EEC). Office for Official Publications of the European Communities. CONSLEG: 1975L0440 31/12/1991.

KHAN F, HUSAIN T and LUMB A (2003) Water quality evaluation and trend analysis in selected watersheds of the Atlantic Region of Canada. Environ. Monit. Assess. 88 221-242.

surface water belonged to the 'excellent' class. On the other hand water quality was strongly affected by agricultural and domestic uses. Therefore priority should be given to minimising these pollution sources to maintain or improve water quality in the basin.

LIOU SM, LIEN S and WANG SH (2004) Generalized water quality index for Taiwan. Environ. Monit. Assess. 96 35-52.

NAGELS JW, COLLEY D and SMITH D G (2001) A water quality index for contact recreation in New Zealand. Water Sci. Technol. 43 (5) 285-292. 
OFFICIAL GAZETTE (1988) Turkish Water Pollution Control Regulation, No. 19919. 4 September 1988, Ankara.

SARGAONKAR A and DESHPANDE V (2003) Development of an overall index of pollution for surface water based on a general classification scheme in Indian context. Environ. Monit. Assess. 89 4367.

SPSS-10.0 (2000) Statistical Package for the Social Sciences. SPSS Inc., Chicago, USA.

WHO (WORLD HEALTH ORGANIZATION) (2004a) Guidelines for Drinking Water Quality ( ${ }^{\text {rd }}$ edn.). Volume 1. Geneva. ISBN 924 1546387.
WHO (WORLD HEALTH ORGANIZATION) (2004b) Rolling Revision of the WHO Guidelines for Drinking Water Quality. Chemical Safety of Drinking-Water: Assessing Priorities for Risk Management.

WHO (WORLD HEALTH ORGANIZATION) (2006a) Establishing National Drinking-Water Standards. Guidelines for Drinking Water Quality Training Pack. http://www.who.int/water sanitation health/dwq/S17.pdf (Accessed on 15 May 2006).

WHO (WORLD HEALTH ORGANIZATION) (2006b) Monitoring and Assessment of Chemical Quality Guidelines for Drinking Water Quality Training Pack. http://www.who.int/water sanitation health/dwq/S09.pdf (Accessed on 10 June 2006). 